International Journal of Current Advanced Research

ISSN: O: 2319-6475, ISSN: P: 2319 - 6505, Impact Factor: SJIF: 5.995

Available Online at www.journalijcar.org

Volume 6; Issue 4; April 2017; Page No. 3337-3341

DOI: http://dx.doi.org/10.24327/ijcar.2017.3341.0266

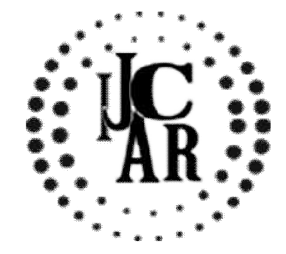

Research Article

\title{
UNLOCKING THE POTENTIAL OF VULNERABLE COMMUNITIES FOR SUSTAINABLE DEVELOPMENT THROUGH CONSERVATION AGRICULTURE PRACTICES IN HOMA BAY COUNTY, IN KENYA
}

\author{
Pamella J. A. Were-Kogogo
}

Jaramogi Oginga Odinga University of Science and Technology, Bondo, Kenya

\section{A R T I C L E I I N F O}

\section{Article History:}

Received $29^{\text {th }}$ January, 2017

Received in revised form $10^{\text {th }}$ February, 2017

Accepted $22^{\text {nd }}$ March, 2017

Published online $28^{\text {th }}$ April, 2017

\section{Key words:}

Sustainable development, climate change, food security, vulnerable communities, livelihoods, ecosystem resilience

\begin{abstract}
A B S T R A C T
Sustainable development especially in rural areas is affected largely by unsustainable agriculture characterizing most areas of Kenya. Homa Bay County is generally characterized by rapid population growth, high poverty levels, impacts of climate change and variability, environmental degradation and food insecurity as key challenges to sustainable development and secure livelihoods. Majority of people in the region depend on agriculture, yet the impacts of climate change and environmental degradation has meant unreliable crop yields. Improving smallholder agricultural systems of vulnerable communities is a key response to these challenges as a means of enhancing sustainable development through increased resilience to climate change. Strengthening agricultural production systems is a fundamental means of improving incomes and food security for the food insecure communities in the county and in Kenya. This project was collaboratively conducted in Homa Bay County of Kenya between different institutions such as Ministry of Agriculture, Research team and communities. The goal of this project was to contribute to sustainable development and improving livelihoods of vulnerable communities through enhanced capacities in innovative Conservation Agricultural (CA) practices. Specific objectives included assessing socio-economic status and capacity of rural communities on CA practices; to train vulnerable communities on maintaining sustainable agricultural systems through innovative but economically viable agricultural practices; and to promote agroforestry and Conservation Agriculture practices. Surveys were done to establish the socio-economic status of communities, level of awareness and practice of CA and to determine crop yields. Capacity building was done through trainings, workshops, Farmer Field Schools and Farmer to Farmer exchange visits. Field trials in experimental plots to compare yields when Conservation Agricultural practices were employed and when farmers used conventional agricultural practices compared with untreated farms. This project has resulted in an increase in farmers' yields after using Conservation Agriculture (CA) practices, improved food security, economic incomes and poverty alleviation, improved soil conditions and enhanced knowledge networks for exchanging experiences established at local level. Community participation has been enhanced in maintaining ecological integrity and resilience of agricultural ecosystems. The project has thus contributed to sustainable management of agricultural ecosystems for improved livelihoods through economically and environmentally viable adaptive approaches to climate change by rural communities in Homa Bay County, Kenya.
\end{abstract}

Copyright $₫ 2017$ Pamella J. A. Were-Kogogo. This is an open access article distributed under the Creative Commons Attribution License, which permits unrestricted use, distribution, and reproduction in any medium, provided the original work is properly cited.

\section{INTRODUCTION}

Agriculture is the mainstay of economy and hence development in Kenya. Sustainable development especially in rural areas is affected largely by unsustainable agriculture characterizing most areas of Kenya. Land degradation is increasingly a key factor affecting agricultural productivity in Africa in general and East Africa in particular.

*Corresponding author: Pamella J. A. Were-Kogogo Jaramogi Oginga Odinga University of Science and Technology, Bondo, Kenya espite general global advancements in farming technologies, from hybrid seed through to fertilizers and mechanization, much of Africa's farming systems, in the last 1-2 decades, have recorded at best stagnation in agricultural productivity and agricultural growth. Though problems are many, complex and varied from community to community, and when the common problems of financial and physical accessibility are taken care of, land degradation is coming out as primary limitation to enhancing and sustaining productivity and agricultural growth. Whiles this is affecting both small and big farmers, Africa's smallholder-subsistence farmers are 
worse affected with drastic and immediate impact on food security and poverty levels.

Most regions in Kenya are characterized by rapid population growth, high poverty levels, climate change and variability impacts, massive environmental degradation and food insecurity. These are key challenges to sustainable development in Kenya. In Homa Bay County in Kenya majority of people depend directly or indirectly on agriculture which is the main economic activity in the region. Farmers also own very small farms which have been highly subdivided due to rapid human population growth rate. Agricultural ecosystems are highly degraded due to unsustainable agricultural practices and impacts of climate change. Soil erosion, unfertile soils and unreliable rainfall lead to dwindling crop yields with subsequent food insecurity, malnutrition and low economic incomes among the local communities. The communities here cannot practice high technological irrigation and farming practices due to high levels of poverty. Participation of experts in agricultural activities is negligible in this region. They are thus highly vulnerable to climate change impacts as they have limited capacities to adapt or mitigate climate and climate variability. High human population levels, land degradation and climate change impact negatively on sustainability of agricultural systems (ecological integrity and resilience) in Siaya County. This leads to unreliable crop yields and hence increased food insecurity, high poverty levels, dwindling local economies hence threat to Sustainable development. Improving smallholder agricultural systems through innovative and economically and environmentally viable methods is a key response to the challenges yield, food insecurity, degraded farms and climate change impacts for enhanced sustainable development in the County.

In order to address issues of development, food security, poverty alleviation and environmental sustainability it is important to pay attention to Sustainable Agriculture and rural development. Promoting agricultural growth as key basis for development and economic growth in general and poverty alleviation and enhanced food security cannot be overemphasized. Creating the right set of actors and conditions available to create a facilitatory enabling environment for sustainable agriculture is a prerequisite to sustainable development. This project was designed to address key barriers to better, higher and sustainable farm productivity in Homa Bay County in Kenya, with main target being smallholder-subsistence farming communities and then main technology being sustainable farming (conservation agriculture).

Strengthening agricultural production systems is a fundamental means of improving incomes and food security for the largest group of food insecure in the world (World Bank 2007; Ravallion and Chen 2007). Improving the resilience of agricultural systems is essential for climate change adaptation and (Conant 2009; Parry et al. 2007; Adger et al. 2003) and a sure means to sustainable development. It is important to move agricultural systems in Homa Bay County to more productive and sustainable levels, while addressing climate change, hence increase food security and adaptive capacity of the food production system. Promotion of household-level agricultural practices and investments that can contribute to improved livelihoods and built competencies of vulnerable communities for sustainable agriculture and climate change resilience is a sure means to sustainable development.

Goal: To contribute to sustainable development and improved livelihoods of vulnerable communities through enhanced capacities in innovative Conservation Agricultural (CA) Practices.

\section{Objectives}

1. To assess socio-economic status and capacity of rural communities on CA practices;

2. To train vulnerable communities on innovative sustainable agricultural practices; and

3. To promote Agroforestry and Conservation Agriculture practices

\section{METHODOLOGY}

This project was conducted in three locations within Homa Bay County in Kenya. Homa Bay County is found on the Western part of Kenya, in the former Nyanza province. It is bordered by Kisii County to the West, Kisumu County to the East and Migori County to the North. It is generally characterized by low and unreliable rainfall patterns, which come twice a year, short rains between September and November and long rains between March and June. Maize remains the major staple crop occupying the majority of land area under cultivation in all study areas.

Purposive selection of three locations in Homa Bay County was done based on areas with highest environmental degradation and poverty indices. A random sample of 250 household was drawn from the total population of households in the study area for inclusion in the research project and women or household heads taken as respondents. The primary data was collected using structured questionnaires administered to farm households, key informant interviews, field observations, and interactive discussions with farmers and farmer groups. Household surveys were conducted using interviews through Participatory Rural Appraisal (PRA) and Focus Group Discussions to determine the socio-economic status and level of awareness and practice of agroforestry and Conservation Agriculture practices. A total of 30 key informant interviews were conducted with stakeholders including government extension workers, local leaders, and some farmers. Field observations provided information that could not be captured using the questionnaire and key informant interviews. Field observations were also a tool used in cross checking the information gathered by the questionnaire. Field observations and informal discussions with farmers and key informants were continuous processes during the entire duration of the research. Data was analysed using Statistical Package for Social Science (SPSS) and Microsoft Excel software to determine frequencies, comparisons, percentages, mean values, standard deviations and correlations.

Capacity building for the selected households (for education and awareness creation) on concepts and principles of Conservation Agriculture (CA) and Farmer-to-Farmer School methodology, Agroforestry and environmental management was conducted through trainings, workshops, Farmer Field Schools and Farmer to Farmer exchange visits. The CA 
systems promoted and adopted by farmers in the study areas include permanent ground cover by using previous year's crop residues (mulching) and intercropping maize with grain legumes such as cowpea (Vigna unguiculata L.), peas and beans as well as integration of agroforestry tree species into CA systems.

Three demonstration farms were established in each location and used for trainings. Seedlings, seeds and other inputs were supplied to target farmers from the Ministry of Agriculture (MoA) and Kenya Forest Service (KFS). Trainings and promotion of $\mathrm{CA}$ practices was done in collaboration with Ministry of Agriculture, Kenya Forest Services, local NGOs, CBOs, Universities, Primary and Secondary Schools. Field trials were conducted in the demonstration farms. Experimental plots were established and using a Complete Randomized Design (CRD), treatments were done on the plots based on Conservation Agricultural practices and conventional agricultural practices. The yields were measured and the means of the various parameters in the experimental plots compared. The means were subjected to Analysis of Variance (ANOVA) to establish whether any significant differences exist in the various treatments. The farmers were trained on laying out the experimental designs, data collection and entry into prescribed data sheets. The study was done for a period of three years from 2011 to 2014. Measurements for various parameters were done for six growing seasons, two in each year for the first two years. The activities conducted on the farms included agroforestry using high value and fastgrowing tree species with multiple benefits for food, fodder, fuel, shade and reducing soil erosion such as sesbania sesbans and gravillea, mulching and intercropping and planting soil cover crops (groundnuts, beans, peas). A set of treatments felt to provide solutions to the problem of low yield due to damaged ecological integrity of farms were tried on demo farms.

General set of CA treatments included:

1. Maize + potatoes + beans

2. Maize + peas + beans

3. Maize + pigeon peas + potatoes

4. Maize + conventional treatment

For soil and water conservation mulching and incorporation of residues and crop rotation for reducing wind and soil erosion, increasing water retention, and improving soil structure and aeration was done. Cover crops like potatoes, cowpea, pigeon pea and beans were introduced on the farms. Maize crops were intercropped with legumes such as cowpeas, peas, and climbing beans introduced as a more productive bean variety. On each farm, a minipond was constructed for the farmers to store water from rainy seasons for supplementary irrigation during dry seasons. This is a cheap way for continuous growing of vegetables and climbing beans for improved protein nutrition and income for the households who cannot afford high technology irrigation.

Continuous monitoring and evaluation is still ongoing to monitor the adoption of these practices by the farmers.

\section{RESULTS AND DISCUSSION}

Many households had very low levels of economic returns, with a number showing signs of malnutrition in children. Many farmers were not aware of concrete CA practices. Many farmers only sighted use of more fertilizers as a key reaction to address the declining agricultural systems. A total of 250 households were trained. These trainings through the different approaches employed enhanced communities members competencies on innovative ideas of $\mathrm{CA}$ and hence an increase in sustainable agriculture has been witnessed. The trainings have led to built in capacity of small-holder farmers on food production, and environmental conservation to ensure improved livelihoods.

During the project period, farmers applying CA realised an average yield two to three times more as compared to conventional plots. Farmers managed a group plot per location as a demo farm for learning (FFS), which was normally demarcated into smaller plots according to the number of treatments decided upon. Farmers reflected on their soil and crop responses with reference to their practices (treatments). The reflections allowed groups members to share and learn from one another. Research team and other stakeholders acted as facilitators for expert input through sessions conducted at some occasions. There were also farmer field days/interactions which were generally around items/issues such as cover crop seed/plants.

Active knowledge base was also enhanced in CA FFS groups through the social learning and knowledge sharing feature of the FFS methodology. It is, however, important to recognize the role played in this by consistent and supportive facilitation given by the project local facilitators both in technical and organizational aspects. Weak and less committed facilitation is likely to translate in poor performance even when group members were interested and committed. The FFS methodology has proven to be a suitable and successful farmer driven approach that goes along well with the learning requirements related to the $\mathrm{CA}$ farming concept. This is because FFS and CA are both multi-faceted and should be implemented in a multi-sectoral perspective. They both engage farming communities in an all-inclusive way. The FFS methodology builds a platform that is conducive to exploration of new as well as traditional farming approaches with self-learning and group-learning exercises, experimentation and local empowerment and as a key feature.

There is established extensive knowledge and experiences sharing at local levels through Farmer-to-farmer visits and workshops and farmer interaction with private sector. The project stimulated and facilitated intensive farmer-tofarmer sharing in supporting the self-learning process. This was achieved through extended and elaborate farmer-tofarmer exchange visits and field-day competitions. These elements of the methodologies added much to the wealth of knowledge and true experience of the CA/FFS farmers. Over $90 \%$ of the participating farmers in the project area rated farmer-to-farmer visits within their locality and beyond as one of the most effective tools in helping learning from fellow farmers and by seeing. The farmer-to-farmer visits were said to help farmers, both the visiting and the visited, enhance their confidence in themselves and their practices. They gave them opportunity to test out what they knew among their peers.

Extensive farmer interaction with private sector through field days brought a cross section of CA stakeholders together from farmers through government department (research, extension, MoA, KFS etc...) representatives and many interest and collaborating players from the NGOs. There is general increasing trend of adoption of $\mathrm{CA}$ practices by 
farmers (Table 1), indicating a wide adoption of CA practices. The farmers have obtained increased food production hence food security in the area. The general increase in crop yields noticed can be attributed to improved ecological integrity of the farms as a result of CA practices such as intercropping with legumes. CA leads to improved resilience of farming systems and livelihood strategies of small holder farmers coping with current climate variability.

Table 1 Level of CA practices

\begin{tabular}{ccccc}
\hline \multirow{2}{*}{$\begin{array}{c}\text { Conservation } \\
\text { Agriculture } \\
\text { Practice }\end{array}$} & Practice Before project & \multicolumn{2}{c}{$\begin{array}{c}\text { Practice during } \\
\text { project period }\end{array}$} \\
\cline { 2 - 5 } & Practice & $\begin{array}{c}\text { No } \\
\text { practice }\end{array}$ & Practice & $\begin{array}{c}\text { No } \\
\text { practice }\end{array}$ \\
\cline { 2 - 5 } & 10 & 90 & 60 & 40 \\
\hline Agroforestry & 5 & 95 & 65 & 35 \\
Mulching & 2 & 98 & 55 & 45 \\
Cover crops & 0 & 100 & 45 & 55 \\
Climbing beans & 0 & 100 & 30 & 70 \\
Miniponds & & & &
\end{tabular}

Crop residues are applied on the soil surface in the dry season soon after harvesting. Farmers aim for at least 30\% soil cover. The mulch cover helps in reducing soil evaporation thereby conserving soil moisture, suppressing weeds through shading, and improving soil fertility by decomposition.

The farms are observed to have reduced erosion, improved soil structure, and greater water retention and reduced yield variability due to weather events. Thus, conservation tillage practices can increase farm system resilience and improve the capacity of farmers to adapt to climate change. At the same time, such practices may reduce carbon losses that occur with ploughing, and also further sequester carbon via residue incorporation and reduced erosion (Lal 1987)). Trees and bushes may also yield products that can either be used for food consumption (fruits), fodder, fuel, building materials, firewood, or sold for cash, leading to greater average household income, and contributing to household risk management via reduced income variability (Ajayi et al. 2009; Franzel et al. 2004). Planting trees and bushes also increases carbon sequestered both above and below ground, thereby contributing to Green House Gas mitigation (Verchot et al. 2007).

Farmers generally acknowledged general effects/impacts both in terms of actual yield increases and for many, even more importantly, the stability in yields. There was an observed ability of CA to enable at least some yield even in poor rainfall scenario. Households obtain continuous supply of cheap protein and improved nutritional value (reduced malnutrition) to families through cowpeas, and climbing beans. The area now has enhanced capacity for development through improved local economies. The women are economically empowered through high and reliable crop yields which provide enough food security and can sell surplus for paying school fees for their children and for buying other basic items. This has strengthened the economy of the area.

Table 2 Crop Yields

\begin{tabular}{ccc}
\hline \multirow{2}{*}{ Crop Type } & $\begin{array}{c}\text { Average crop yield per household (No. of } \\
\text { 90kg sack per hectare) }\end{array}$ \\
\cline { 2 - 3 } & Without CA & With CA \\
\hline Beans & 2 & 7 \\
Maize & 5 & 20 \\
\hline
\end{tabular}

There is an increase in more households intercropping cover crops and maize on their farms, with improved soil fertility and yields. Climbing beans occupy less space but with very high productivity hence more yields and allows growth of maize in between. It enriches the soil. Cover crops provide cheap protein to the households. Cover crops and rotation patterns alleviate potential weed problems because herbicides are not available or accessible to poor smallholders due to poverty. Leaving residues on the field was also a method of covering the soil. Continuous cover between main crops can reduce erosion, build soil organic matter, and improve the water balance, leading to higher and more stable yields on the alleys sown to main crops (Blanco and Lal, 2008). Cover crops ensure that the soil is not left bare after harvest. They produce easily decomposable biomass and replenish soil fertility (Matata et al. 2010; Sanchez 1999). In terms of adaptation, such practices can reduce erosion and enhance water retention, both of which should enhance resilience to drought (Conant 2009; Peterson and Westfall 2004).

Participating farmers have shown through subjective statements and especially yield figures that the trend and potential was positive. Most farmers indicated stabilisation of yields even in below-normal rainfall seasons, as a key incentive to adopt (even more than the factor of actual yield increase). Intercropping with cowpeas, pumpkins, beans and other mostly indigenous crops enhanced overall productivity of the land and even more critically for soil fertility provided increased source of biomass.

The project has shown through the project period a positive and growing trend in effects on food security and farm incomes. In a situation where households are running out of food for increasingly more months -3 to 4 months with 1 to 2 of them classified as severe, even one more month guarantee of food was regarded as a significant and desired development. Of the households whose food availability data was analysed over the two years, number of households suffering severe food shortage declined from $75 \%$ to $50 \%$. Overall food deficit period declined from 4 months to 3 months. It would be useful to follow through this assessment to check the trend over a longer period. Effect from change in income levels was more dramatic in groups/ households involved with intensive CA practices. The incomes were significant and made noted impact on the household livelihoods and their ability to invest in capital items.

The incomes from vegetable provided a steady almost-yearround source of income.

\section{CONCLUSIONS AND RECOMMENDATIONS}

This project has led to improved economies due to increased crop yields and food security in Homa Bay County.

There are well established and extensive knowledge networks on $\mathrm{CA}$ and hence sustainable agricultural practices. Farmers interact amongst themselves and with both private and government officers in relation to maintenance of sustainable management of agricultural ecosystems for improved livelihoods. Community participation in maintaining ecological integrity and resilience of agricultural ecosystems has been enhanced. 
Adoption or uptake of innovative ideas of CA by vulnerable communities has been enhanced through economically viable and environmentally friendly approaches beneficial in addressing community needs.

It can be concluded that competencies of communities in innovative ideas for sustainable development can be achieved through cheap methods involving participatory approach to environmental management of ecosystems as an important aspect for sustainable development.

It is recommended that more trainings and knowledge sharing networks be created. There is need to upscale this project by replicating these technologies in the whole county and country in general. It is possible to use these technologies to increase production in a sustainable way in Kenya resulting in improved and sustained productivity, increased profits and food security while preserving and enhancing the natural resource base and the environment. The results of this project can be used by the county to inform policy during implementation of its County Integrated Development Plan which has set goals on sustainable development and environmental conservation.

\section{References}

Adger, W.N., S. Huq, K. Brown, D. Conway and M. Hulme. 2003. Adaptation to climate change in the developing world. Progress in Development Studies, 3: 179-195.

Ajayi, O.C., F.K. Akinnifesi, G. Sileshi and W. Kanjipite. 2009. Labour inputs and financial profitability of conventional and agroforestry-based soil fertility management practices in Zambia. Agrekon, 48(3): 276293.

Blanco, H. and R. Lal. 2008. Principles of Soil Conservation and Management. New York: Springer.

Conant, R.T. 2009. Rebuilding Resilience: Sustainable Land Management for Climate Mitigation and Adaptation. Technical Report on Land and Climate Change for the Natural Resources Management and Environment Department. Rome: Food and Agriculture Organization of the United Nations.

FAO. 2009. Food Security and Agricultural Mitigation in Developing Countries: Options for Capturing Synergies. Contributing Authors: W. Mann, L. Lipper, T. Tennikeit, N. Mc Carthy and G. Branca. Rome, Italy: Food and Agriculture Organization of the United Nations.

Franzel, S., G.L. Denning, J-P. Lillesø-Barnekow and A.R. Mercado. 2004. Scaling up the impact of agroforestry: Lessons from three sites in Africa and Asia. World Agroforestry Centre, Kenya and the Philippines. Agroforestry Systems, 61-62(1-3): 329-344.
Lal, R. 1987. Managing the soils of sub-Saharan Africa. Science, New Series, 236(4805): 1069-1076.

Matata, P .Z., O.C.Ajayi, P.A.Oduol and Aggrey Agumya. 2010. Socio-economic factors influencing adoption of improved fallow practices among smallholder farmers in western Tanzania. African Journal of AgriculturalResearch, 5(8): 818-823.

Parry, M.L., O.F. Canziani, J.P. Palutikof, P.J. van der Linden and C.E. Hanson (eds). 2007. Climate Change 2007: Impacts, Adaptation and Vulnerability. Contribution of Working Group II to the Fourth Assessment Report of the Intergovernmental Panel on Climate Change. Cambridge, UK: Cambridge University Press: pp. 391-431.

Paustian, K., J. Brenner, M. Easter, K. Killian, S. Ogle, C. Olson, J. Schuler, R. Vining and S. Williams. 2009. Counting carbon on the farm: Reaping the benefits of carbon offset programs. Journal of Soil and Water Conservation, 64: 36A-40A.

Peterson, G.A. and D.G. Westfall. 2004. Managing Precipitation Use in Sustainable Dryland Agroecosystems. Annals of Applied Biology, 144: 127138.

Ravallion, M. and S. Chen. 2007. China's (Uneven) progress Against Poverty. Journal of DevelopmentEconomics, 82(1): 1-42.

Sanchez, P. 1999. Improved Fallows Come of Age in the Tropics Agroforestry Systems 47: 3-12, Netherlands: Kluwer Academic Publishers.

Smith, P., D. Martino, Z. Cai, D. Gwary, H.H. Janzen, P. Kumar, B. McCarl, S. Ogle, F. O’Mara, C. Rice, R.J. Scholes, O. Sirotenko, M. Howden, T. McAllister, G. Pan, V. Romanenkov, U. Schneider, S. Towprayoon, M. Wattenbach and J.U. Smith. 2008. Greenhouse gas mitigation in agriculture. Philosophical Transactionsof the Royal Society B, 363(1492): 789-813

Verchot, L.V., M. Van Noordwijk, S. Kandji, T. Tomich, C. Ong, A. Albrecht, J. Mackensen, C. Bantilan, K.V. Anupama and C. Palm. 2007. Climate Change: Linking adaptation and mitigation through agroforestry. Mitigation and Adaptation Strategies for Global Change, 12: 901-918.

World Bank. 2007. Agriculture for Development: World Development Report 2008. Washington, DC: The World Bank.

\section{How to cite this article:}

Pamella J. A. Were-Kogogo (2017) 'Unlocking The Potential Of Vulnerable Communities For Sustainable Development Through Conservation Agriculture Practicesin Homa Bay County, In Kenya', International Journal of Current Advanced Research, 06(04), pp. 3337-3341. DOI: http://dx.doi.org/10.24327/ijcar.2017.3341.0266 